\title{
Reverse-Transcription Polymerase Chain Reaction Detection of Citrus Tristeza Virus in Aphids
}

Prem Mehta, R. H. Brlansky, and S. Gowda, University of Florida, Citrus Research and Education Center, Lake Alfred, FL 33850; and R. K. Yokomi, USDA-ARS Horticultural Research Laboratory, Orlando, FL 32803

\begin{abstract}
Mehta, P., Brlansky, R. H., Gowda, S., and Yokomi, R. K. 1997. Reverse-transcription polymerase chain reaction detection of citrus tristeza virus in aphids. Plant Dis. 81:1066-1069.

A rapid and simple reverse-transcription polymerase chain reaction (RT-PCR) method was developed for the detection of citrus tristeza virus (CTV) in three aphid species. Seven CTV isolates from a worldwide isolate collection were used for aphid acquisition feeding by three aphid species. These included the most efficient CTV vector, the brown citrus aphid, Toxoptera citricida; the melon aphid, Aphis gossypii; and the green peach aphid, Myzus persicae, a non-vector for CTV. A short procedure for nucleic acid extraction from single or groups of aphids was developed. Nucleic acid extracts from 1, 3, 5, and 10 aphids with acquisition-access periods of 24 and $48 \mathrm{~h}$ were reverse transcribed and amplified using primers for the coat protein gene of the Florida B3 (T-36) isolate of CTV. PCR-amplified fragments of approximately 670 bp were obtained from all the isolates tested and the amplified product from the aphids fed on citrus infected with isolate B3 was confirmed as the CTV coat protein gene by digesting with various restriction enzymes. This technique will be useful in investigations of CTV-vector-plant interactions and CTV epidemiology.
\end{abstract}

Additional keywords: acquisition, semi-persistent

Citrus tristeza virus (CTV) is an economically important pathogen of citrus in many production areas of the world. It causes two important diseases-a decline of citrus on sour orange (C. aurantium L.) rootstock (CTV-decline) and stem pitting of many cultivars regardless of rootstock. The virus is a phloem-limited closterovirus, consisting of $11 \mathrm{~nm} \times 2,000 \mathrm{~nm}$ flexuous particles and has a positive sense single-stranded RNA genome of 19,296 nt, which makes it the largest known plant virus genome $(2,15)$. CTV is vectored by aphids in a noncirculative semipersistent manner (16). Of the aphid species listed as vectors, the most studied ones are Toxoptera citricida (Kirkaldy), Aphis gossypii (Glover), and Aphis spiraecola Patch (1). Of these, T. citricida, the brown citrus aphid (BrCA), is the most important and efficient CTV vector $(5,13)$. Single $T$. citricida have been reported to be $80-100 \%$ efficient in transmitting many CTV isolates (17). A. gossypii has also been shown to be an efficient vector for some CTV isolates (1). Hosts for the BrCA are plant species in the Rutacaeae and include most Citrus

Corresponding author: R. H. Brlansky

Florida Agricultural Experiment Station Journal Series No. R-05268.

Accepted for publication 10 June 1997.

Publication no. D-1997-0703-02R

(C) 1997 The American Phytopathological Society spp., hybrids, and other citrus relatives (6). Tristeza problems, either CTV-decline or stem pitting of orange or grapefruit $(C$. paradisi Macf.), have generally occurred whenever BrCA has appeared (12).

Recently, BrCA was discovered in the continental U.S. in Florida (8). Because field isolates of CTV are a complex of various strains, studies on the transmission of endemic and exotic isolates of CTV by aphid vectors are important to better understand the nature of these isolates (or strains) (3). To facilitate investigations of CTV-BrCA-plant interactions, we needed to develop a rapid method for the detection of CTV in single and up to 10 aphids. This report describes the development of a short procedure for nucleic acid extraction from single or groups of aphids and detection of CTV using reverse-transcription polymerase chain reaction (RT-PCR).

\section{MATERIALS AND METHODS}

Virus isolates and aphid species. Seven CTV isolates from the CTV exotic isolate collection at the USDA Beltsville Agricultural Research Center, Beltsville, MD were used in this study. These were B3, B6, B14, B151, B152, B165, and B199. Their geographic origin and indicator symptoms (based on the standard host range [7]) are listed in Table 1.

All CTV isolates were graft inoculated or aphid transmitted into Madam vinous sweet orange (Citrus sinensis [L.] Osbeck) plants and these infected plants were used for virus acquisition by aphids. The B3 isolate also was graft inoculated into Kaffir lime or combava (C. hystrix Hort. ex Tan.).

Aphid species used for virus acquisition were two vectors, $T$. citricida and $A$. gossypii, and a nonvector species, Myzus persicae (Sulzer). Colonies of T. citricida were maintained on healthy Carrizo citrange $(C$. sinensis $\times$ Poncirus trifoliata $)$ seedlings, A. gossypii were reared on okra (Hibiscus esculentus), and M. persicae were reared on 'California Wonder' pepper (Capsicum annum L.) and cabbage (Brassicae oleracea L. var. capitata).

Acquisition of CTV by vector and non-vector aphid species. Aphids from each vector species, $T$. citricida and $A$. gossypii, and from the non-vector species, $M$. persicae, were placed on CTV-infected citrus plants in separate aphid-proof cages. After acquisition-access periods (AAP) of 24 and $48 \mathrm{~h}$, aphids were collected using a fine camel hair brush and stored at $-20^{\circ} \mathrm{C}$. Aphids fed on healthy citrus plants as controls also were collected and stored as described.

Nucleic acid extraction from aphids and citrus tissues. A short extraction procedure was designed. One, 3, 5, and 10 aphids were placed in sterile microfuge tubes; 25, 50, 75, and $100 \mu \mathrm{l}$ of cold extraction buffer $(10 \mathrm{mM}$ Tris- $\mathrm{HCl}, 1 \mathrm{mM}$ EDTA, pH 8.0) was added, respectively; and the mixture was ground thoroughly with a plastic pestle. Extracts from $100 \mathrm{mg}$ of the petiole and the bark tissues from healthy citrus were prepared by grinding the materials to a powder in liquid nitrogen in a sterile mortar and pestle to which $1 \mathrm{ml}$ of extraction buffer was added. Immediately after homogenization, the solutions were vortexed briefly and centrifuged at $15,000 \mathrm{rpm}$ for $5 \mathrm{~min}$, and the supernatant was collected in sterile microfuge tubes. Twenty, 40, 60, and $80 \mu \mathrm{l}$ of the supernatant from $1,3,5$, and 10 aphids, respectively, and $200 \mu \mathrm{l}$ from the citrus tissue extracts were transferred to sterile microfuge tubes and 10, 20,30, and $40 \mu \mathrm{l}$ of the Gene Releaser (Bio Ventures, Inc., TN) in case of aphids and $50 \mu \mathrm{l}$ in case of leaf tissues were added, respectively. The solutions were mixed and heated for $20 \mathrm{~min}$ at $75^{\circ} \mathrm{C}$ and centrifuged at $15,000 \mathrm{rpm}$ for 15 $\min$ at $4^{\circ} \mathrm{C}$. The supernatant was collected into sterile microfuge tubes, and $0.1 \mathrm{vol}$ of $3 \mathrm{M}$ sodium acetate and $2.5 \mathrm{vol}$ of $95 \%$ ethanol were added. The tubes were inverted to mix the contents and were incubated for $30 \mathrm{~min}$ at $-70^{\circ} \mathrm{C}$. After incuba- 
tion, the tubes were centrifuged at 15,000 $\mathrm{rpm}$ for $15 \mathrm{~min}$ at $4^{\circ} \mathrm{C}$, and the supernatant was discarded. The pellet was washed with $500 \mu \mathrm{l}$ of $70 \%$ ethanol, dried for 10 min under vacuum, resuspended in $20 \mu \mathrm{l}$ of sterile distilled water, and stored at $-20^{\circ} \mathrm{C}$.

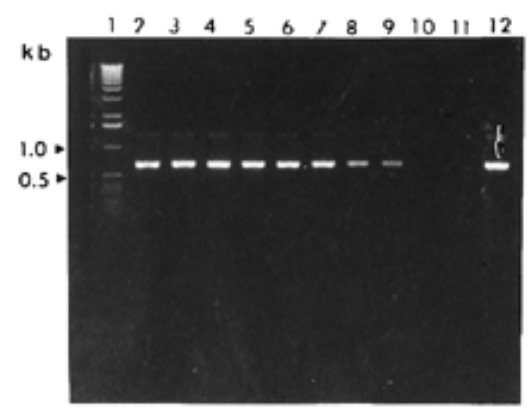

Fig. 1. Polymerase chain reaction (PCR)amplified product of B-3 (T-36) isolate of citrus tristeza virus (CTV) from individual and multiple viruliferous Toxoptera citricida. Amplification of approximately 670-bp fragments with the primer pair $\mathrm{C} 100$ and C74. An aliquot $(5 \mu \mathrm{l})$ of the $50 \mu \mathrm{l}$ PCR mixture was analyzed in a $1 \%$ agarose gel. Lane 1, 1-kb ladder size marker (75 bp-12 kb, Gibco BRL); lanes 2, 4, 6 , and 8 , PCR-amplified product from viruliferous $10,5,3$, and single $T$. citricida, respectively, with an acquisition-access period of $48 \mathrm{~h}$; lanes 3, 5, 7, and 9, PCR-amplified product from viruliferous $10,5,3$, and $1 \mathrm{~T}$. citricida, respectively, with an acquisition-access period of $24 \mathrm{~h}$; lanes 10 and 11, PCR-amplified product from individual nonviruliferous $T$. citricida and healthy citrus bark tissue, respectively; lane 12, PCR-amplified CTV-DNA fragment from the plasmid containing the CTV (B3) $3^{\prime}$ region including the $\mathrm{CP}$ gene.

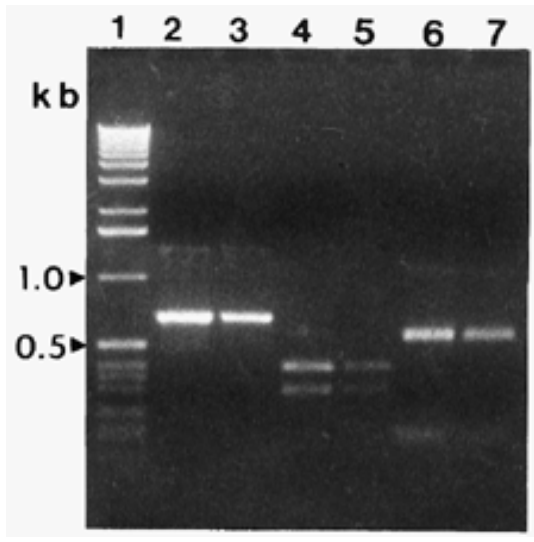

Fig. 2. Restriction digestion analysis of polymerase chain reaction (PCR)-amplified fragments of B3 (T-36) isolate of CTV from individual Toxoptera citricida. Lane 1, 1-kb ladder size marker (75 bp-12 kb, Gibco BRL, NY); lanes 2 and 3, undigested CTV-DNA from cloned CTV CP gene and PCR-amplified fragment from individual $T$. citricida, respectively; lanes 4 and 5, BstEII digestion of cloned CTV $\mathrm{CP}$ and from individual T. citricida, respectively; lanes 6 and 7, ClaI digestion of cloned CTV CP fragment and from individual T. citricida, respectively.
Reverse transcription. The first strand cDNA was synthesized using the nucleic acid extracted from the aphid species as templates and $\mathrm{C} 74$ as the primer. The total reaction volume was $25 \mu \mathrm{l}$, which contained 15 units of AMV reverse transcriptase (Promega, Madison, WI), 25 units of rRNasin (Promega, Madison, WI), and $0.24 \mathrm{mM}$ each of dATP, dCTP, dGTP, dTTP (Idaho Technology, Inc., ID). The contents were mixed gently and incubated at $42^{\circ} \mathrm{C}$ for $60 \mathrm{~min}$.

PCR amplification. The primers $\mathrm{C} 100$ (GGCGGAATTCGACGACGAAACAAA GAAA, viral sense polarity with an EcoRI site at the $5^{\prime}$ end) and C74 (GAAGATCTTCAACGTGTGTTGAATTTCC, complementary sense polarity with $B g$ III site at the $5^{\prime}$ end) (unpublished) were used to amplify the coat protein (CP) gene of CTV. The primers $\mathrm{C} 100$ and $\mathrm{C} 74$ were designed based on the nucleotide sequence for the $\mathrm{CP}$ gene of isolate $\mathrm{B} 3$ with unique restriction sites at the ends to facilitate further cloning and amplification of a 670-bp CP gene product from the plasmid containing the $\mathrm{CP}$ gene. The amplification was per- formed in a final volume of $50 \mu \mathrm{l}$ containing $10 \mu \mathrm{l}$ of cDNA; 5 units of Taq DNA polymerase (Promega, Madison, WI); 2.5 $\mathrm{mM} \mathrm{MgCl} 2 ; 0.12 \mathrm{mM}$ each of dATP, dCTP, dGTP, and dTTP (Idaho Technology Inc., ID); and $0.3 \mu \mathrm{M}$ of each primer. PCR was performed in a programmable thermal controller (model PTC-100, MJ Research Inc., Watertown, MA) using the following parameters: one cycle at $94^{\circ} \mathrm{C}$ for $2 \mathrm{~min}$; 35 cycles at $94^{\circ} \mathrm{C}$ for $5 \mathrm{~s}$ (denaturation), $48^{\circ} \mathrm{C}$ for $10 \mathrm{~s}$ (annealing), and $72^{\circ} \mathrm{C}$ for 10 $\mathrm{s}$ (primer extension); followed by one cycle at $72^{\circ} \mathrm{C}$ for $2 \mathrm{~min}$.

PCR-amplified fragments from the aphids containing the B3 isolate of CTV were digested with BstEII and ClaI (New England Biolabs, MA). The digested fragments and nondigested fragments were electrophoresed in $1 \%$ agarose gels, respectively, in Tris-acetate-EDTA buffer and detected using UV light after staining in ethidium bromide.

\section{RESULTS}

Detection of CTV in single and multiple viruliferous $T$. citricida by RT-PCR.

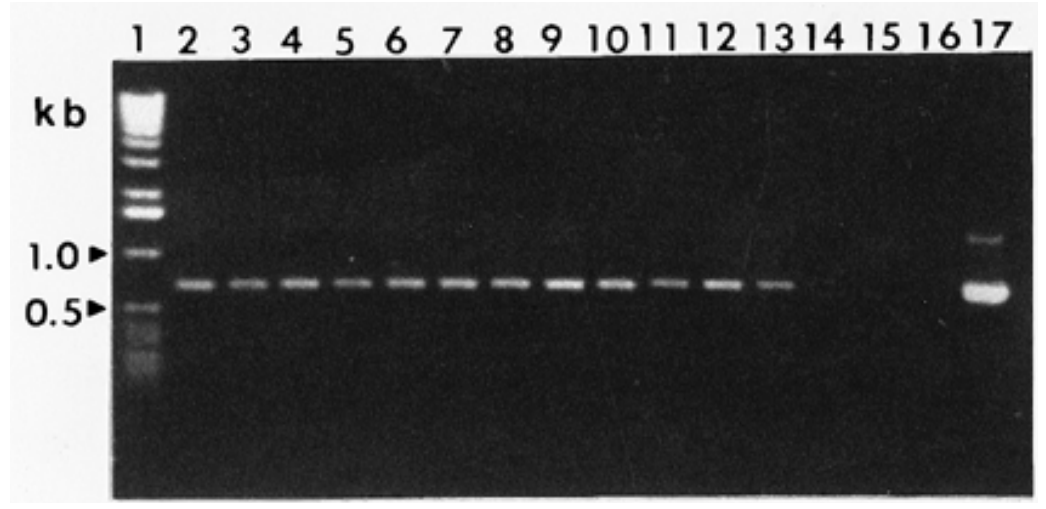

Fig. 3. Polymerase chain reaction (PCR)-amplified product of various isolates of citrus tristeza virus (CTV) from a group of single and multiple T. citricida. Amplification of approximately 670-bp fragments with the primer pair $\mathrm{C} 100$ and $\mathrm{C} 74$. An aliquot $(5 \mu \mathrm{l})$ of the $50 \mu \mathrm{l}$ PCR mixture was analyzed in a $1 \%$ agarose gel for all isolates except for isolate B199. Lane 1, 1-kb ladder size marker (75 bp$12 \mathrm{~kb}$, Gibco BRL, NY); lanes 2-13, a group of three and single T. citricida with CTV isolates B14 (lanes 2, 3), B165 (lanes 4, 5), B6 (lanes 6, 7), B199 (lanes 8, 9), B151 (lanes 10, 11), B152 (lanes $12,13)$, respectively; lanes 14 and 15 , no PCR-amplified products from a group of three and single nonviruliferous T. citricida; lane 16, no amplified product from healthy citrus bark tissue and lane 17 , the amplified product from the plasmid positive control.

Table 1. Origin and biological properties of the citrus tristeza virus isolates used for virus acquisition by aphid species

\begin{tabular}{lccc}
\hline Virus isolate & Geographic origin & Disease caused $^{\mathbf{a}}$ & Indicator symptoms $^{\mathbf{b}}$ \\
\hline B3 & Florida & CD & MoSY, MoVC \\
B6 & California & CD, OSP, GSP & SvSY, SvVC \\
B14 & Brazil & CD, OSP, GSP & SvSY, SvVC \\
B151 & California & SSO & MVC \\
B152 & California & CD, GSP & SSY, MoVc \\
B165 & India & CD, OSP, GSP & SSY, SVC \\
B199 & Israel & CD, GSP, OSP & MoSY, MoVC \\
\hline
\end{tabular}

${ }^{a} \mathrm{CD}=$ citrus decline, OSP $=$ orange (Citrus sinensis $[\mathrm{L}$.$] Osbeck) stem pitting, GSP =$ grapefruit $(C$. paradisi Macf.) stem pitting, SSO = stunting in sweet orange on sour orange (C. aurantium $\mathrm{L}$.).

${ }^{\mathrm{b}}$ MSY $=$ mild seedling yellows in Eureka lemon $(C$. limon [L.] Burm f.) or sour orange $(C$. aurantium L.), MoSY = moderate seedling yellows, SSY = strong seedling yellows, SvSY = severe seedling yellows, $\mathrm{MVC}=$ mild vein clearing in Mexican lime (C. aurantifolia [Christm.] Swing.), MoVC $=$ moderate vein clearing in Mexican lime, $\mathrm{SVC}=$ strong vein clearing in Mexican lime, $\mathrm{SvVC}=$ severe vein clearing in Mexican lime. 
RT-PCR-amplified fragments of approximately 670 bp were obtained using C100 and C74 primers with the devised nucleic acid extraction procedure (Fig. 1). Amplified fragments corresponding in size to the CTV-CP gene were obtained from 10, 5, 3, and single $T$. citricida fed on B3-infected plants for AAP of 48 and $24 \mathrm{~h}$, respectively. No DNA fragments were obtained either from healthy citrus leaves or nonviruliferous $T$. citricida.

Restriction digestion analysis. Restriction digests of RT-PCR-amplified fragments from single $T$. citricida fed on the B3 isolate of CTV yielded fragments with both of the restriction enzymes BstEII and ClaI (Fig. 2). The sizes of these fragments agreed with predicted values (384 and 286 bp) for BstEII and (571 and $99 \mathrm{bp}$ ) for ClaI estimated from the sequence of the $\mathrm{CP}$ gene of CTV $(11,15)$, indicating that $T$. citricida acquired CTV during the acquisition-access period on infected citrus.

Detection of various CTV isolates in single and multiple viruliferous $T$. citricida by RT-PCR. Six different CTV isolates designated as B14, B165, B6, B199, $\mathrm{B} 151$, and B152 were detected from single and groups of three $T$. citricida by RT-PCR (Fig. 3). The intensity of the bands were similar for all isolates except B199. In order to obtain the detection of B199 shown in Fig. 3, $10 \mu \mathrm{l}$ of PCR-amplified product was loaded in the agarose gel as compared to $5 \mu \mathrm{l}$ for the other isolates. No differences were observed in detection from three or single aphids (Fig.3). DNA fragments were not amplified either from

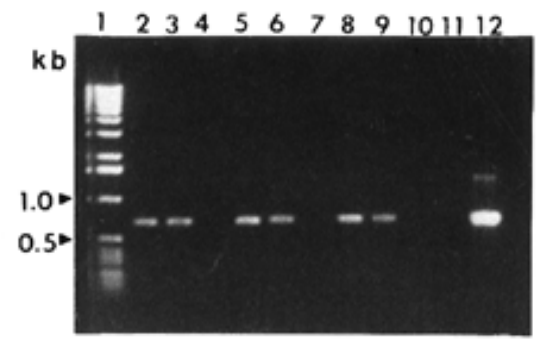

Fig. 4. Polymerase chain reaction (PCR)amplified product of B3 (T-36) isolate of citrus tristeza virus (CTV) from different aphid species. These aphids were given an acqui-sitionaccess period of $48 \mathrm{~h}$ on CTV-infected citrus plants. Amplification of approximately 670-bp fragments with the primer pair $\mathrm{C} 100$ and $\mathrm{C} 74$. An aliquot $(5 \mu \mathrm{l})$ of the $50 \mu \mathrm{l} \mathrm{PCR}$ mixture was analyzed in a $1 \%$ agarose gel. Lane $1,1-\mathrm{kb}$ ladder size marker (75 bp-12 kb, Gibco, BRL, NY); lanes 2 and 3, PCR-amplified product from groups of three and single Toxopera citricida with B3 isolate of CTV; lanes 5 and 6, PCR-amplified product from groups of three and single A. gossypii with B3 isolate of CTV; lanes 8 and 9, PCR-amplified product from groups of three and single $M$. persicae with B3 isolate of CTV; lanes 4, 7, and 10, no amplified product from individual nonviruliferous $T$. citricida, A. gossypii and M. persicae, respectively; lane 11, no amplified product from healthy citrus bark tissue and lane 12, the PCRamplified product from the plasmid control. healthy citrus tissues or nonviruliferous $T$. citricida.

Detection of CTV in T. citricida, A. gossypii and $M$. persicae by RT-PCR. RTPCR-amplified fragments of approximately 670 bp corresponding to the CP gene were obtained from single and groups of three $T$. citricida, A. gossypii, and $M$. persicae fed on B3 isolate of CTV for an AAP of $48 \mathrm{~h}$ (Fig. 4). The intensity of the bands obtained from $A$. gossypii and $M$. persicae were similar to those obtained with $T$. citricida, the most efficient CTV vector. No DNA fragments were obtained either from healthy citrus leaves or nonviruliferous $T$. citricida, A. gossypii, and M. persicae.

\section{DISCUSSION}

RT-PCR was successfully used to detect CTV in single and groups of 3,5 , and 10 aphids. This method detected CTV in three aphid species-T. citricida, A. gossypii, and $M$. persicae. No bands were obtained from either healthy citrus tissues or nonviruliferous aphids.

The described procedure for nucleic acid extraction is simple, efficient, and can be used on a large number of samples in a short period of time. Because RT-PCR amplifies nucleic acids, it is useful in overcoming many difficulties encountered with serological methods, such as low antigen titer, availability of antibodies, and cross reactivity of antibodies with heterologous antigens. RT-PCR is faster than methods such as squash blot and dot blot hybridization and is not based on the use of radioisotopes such as ${ }^{32} \mathrm{P}$. The sensitivity of the method shown here in detecting CTV in single as well as multiple aphids should allow the processing of composite samples of aphid vectors.

Enzyme-linked immunosorbent assay has been used to detect CTV in plants and 11 aphid species, including many nonvectors of CTV (4). Similarly, we found that CTV was detected in a nonvector, $M$. persicae. Apparently, CTV is acquired by different species of aphids independent of their ability to transmit it. The exact location of semipersistently transmitted closteroviruses like CTV in aphids is unknown. Semipersistent, noncirculative transmission is characterized by an increasing transmission probability with an increase in acquisition period and a retention period of several days (10). This suggests that virus can accumulate in the vector and resist dissociation. Since infectivity is not retained through a molt, the virus retention site is likely the cuticle or intima that lines the foregut. RT-PCR could be useful in determining if virus is located in dissected mouthparts of vector and nonvector aphids. If both vector and nonvectors contain virus in mouthparts, then only the ability to have virus released is the difference between vectors and nonvectors. Immunolabeling coupled with electron microscopy also may help provide more information on virus location in the aphid. Murant et al. (14) found virus-like particles of anthriscus yellows virus and parsnip yellow fleck virus in a matrix material attached to the intima lining of the pharynx. Attachment of the virus to its vector might be either the consequence of attachment of the viral protein to cell membranes of the lining of the alimentary canal or indirectly by helper factors (9). Understanding the interaction of plant viruses in vectors and nonvectors may lead to novel ways to disrupt acquisition or transmission.

\section{ACKNOWLEDGMENTS}

This study was supported by USDA/ARS/IFAS Cooperative Agreement 48-6617-4-108. We thank the USDA, ARS Foreign Disease Science Research Unit, Frederick, MD, for use of the facilities for some of the aphid-CTV acquisition and V. Damsteegt and C. Gouin-Behe for assistance.

\section{LITERATURE CITED}

1. Bar-Joseph, M., Garnsey, S. M., and Gonsalves, D. 1979. The closteroviruses: A distinct group of elongated plant viruses. Adv. Virus Res. 25:93-168.

2. Bar-Joseph, M., and Lee, R. F. 1989. Citrus tristeza virus. AAB Descriptions of Plant Viruses AAB No. 353 (No. 33 revised).

3. Broadbent, P., Brlansky, R. H., and Indsto, J. 1996. Biological characterization of Australian isolates of citrus tristeza virus and separation of subisolates by single aphid transmission. Plant Dis. 86:329-333.

4. Cambra, M., Hermoso de Mendoza, A. Moreno, P., and Navarro, L. 1982. Use of enzyme-linked immunosorbent assay (ELISA) for detection of citrus tristeza virus (CTV) in different aphid species. Proc. Int. Soc. Citriculture 1:444-448.

5. Costa, A. S., and Grant, T. J. 1951. Studies on transmission of the tristeza virus by the vector, Aphis citricidus. Phytopathology 41:105-113.

6. Denmark, H. A. 1978. The brown citrus aphid, Toxoptera citricida (Kirkaldy). Page 2 in: Fla. Dept. Agric. \& Consumer Serv. DPI. Entomology Circ. No. 194.

7. Garnsey, S. M., Gumpf, D. J., Roistacher, C. N., Civerolo, E. L., Lee, R. F., Yokomi, R. K., and Bar-Joseph, M. 1987. Toward a standardized evaluation of the biological properties of citrus tristeza virus. Phytophylactica 19:151-157.

8. Halbert, S. E. 1996. Entomology Section: Citrus. In: Tri-ology. Div. Plant Ind. 34(6):8.

9. Harris, K. F. 1977. An ingestion-egestion hypothesis of noncirculative virus transmission. Pages 165-220 in: Aphids as Virus Vectors. K. F. Harris and K. Maramorosch, eds. Academic Press, New York.

10. Harris, K. F. 1981. Arthropod and nematode vectors of plant viruses. Annu. Rev. Phytopathol. 19:391-426.

11. Karasev, A. V., Boyko, V. P., Gowda, S., Nikolaeva, O. V., Hilf, M. E., Koonin, E. V., Niblett, C. L., Cline, K., Gumpf, D. J., Lee, R. F., Garnsey, S. M., Lewandowski, D. J., and Dawson, W. O. 1995. Complete sequence of the citrus tristeza virus RNA genome. Virology 208:511-520.

12. Knorr, L. C., and Ducharme, E. P. 1951. This is tristeza-Ravager of Argentina's citrus industry. Citrus Magazine (Florida) 13:17-19.

13. Meneghini, M. 1946. Sôbre a natureza e transmissibilidade do doenca "tristeza" dos citrus. Biologico 12:285-287.

14. Murant, A. F., Roberts, I. M., and Elnager, S. 1976. Association of virus-like particles with the foregut of the aphid Cavariella algopodii transmitting the semipersistent viruses an- 
thriscus yellows and parsnip yellow fleck. J. Gen. Virol. 31:47-57.

15. Pappu, H. R., Karasev, A. V., Anderson, E. J., Pappu, S. S., Hilf, M. E., Febres, V., Eckloff, R. M. G., McCaffery, M., Boyko, V., Gowda, S., Dolja, V. V., Koonin, E. V., Gumpf, D. J., Cline, K., Garnsey, S. M., Dawson, W. O., Lee, R. F., and Niblett, C. L. 1994. Nucleotide sequence and organization of eight $3^{\prime}$ open reading frames of the citrus tristeza closterovirus genome. Virology 199:35-46.

16. Shepherd, R. J. 1977. Intrinsic properties and taxonomy of aphid-borne viruses. Pages 126136 in: Aphids as Virus Vectors. K. F. Harris and K. Maramorosch, eds. Academic Press, New York.
17. Yokomi, R. K., Lastra, R., Stoetzel, M. B., Damsteegt, V. D., Lee, R. F., Garnsey, S. M. Gottwald, T. R., Rocha-Pena, M. A., and Niblett, C. L. 1994. Establishment of the brown citrus aphid (Homoptera: aphididae) in Central America and the Caribbean Basin and transmission of citrus tristeza virus. J. Econ. Entomol. 87:1078-1085. 